\title{
The Subordination of Women in Customary Law of Lampung Pepadun
}

\author{
H S Asnawi', M Yusuf ${ }^{2}$, M A Mushodiq ${ }^{3}$, A P Maba ${ }^{4}$ \\ Institute for Islamic Study Ma'arif NU (IAIMNU) Metro, Purwosari, Metro Lampung, \\ Indonesia ${ }^{1,2,3,4}$ \\ \{habibshulton1708@gmail.com ${ }^{1}$,yusufiaimnu@gmail.com², agusmushodiq92@gmail.com ${ }^{3}$, \\ aprezopm@gmail.com $\left.{ }^{4}\right\}$
}

\begin{abstract}
This article is about the facts of injustice and discrimination against indigenous women of Lampung Pepadun Marga Anak Tuha. The first injustice in the context of heirs, daughters and wives or widows in Customary Law of Lampung Pepadun Marga Anak Tuha is not entitled to the right of inheritance. The second injustice in the context of marriage, if a divorced widow dies to do marriage with a male outside the relatives of the male family then the husband is required to perform the traditional ceremony. If the customary requirement is not implemented then the widow is customarily considered dead and will be subject to customary sanctions. The focuses of this research are (1) the right of women in the customary law of Lampung Pepadun (2) efforts in upholding the women fairness and gender equity of Lampung Pepadun Marga Anak Tuha's Indigenous people. The results of this research are (1) right of women in the customary law of Lampung Pepadun Marga Anak Tuha is inconsistent and contradictory to the principles and principles contained in the Convention on the Elimination of All Forms of Discrimination Against Women (CEDAW), and Efforts to uphold gender equality and fairness of indigenous people of Lampung Pepadun Marga Anak Tuha is need for socializing gender-based education and human rights. Socialization and understanding is not only in designation for women, but also the wider community and traditional leaders Lampung Pepadun Marga Anak Tuha
\end{abstract}

Keywords: Women's Justice Rights, Customary Law of Lampung Pepadun Marga Anak Tuha and CEDAW.

\section{Introduction}

Islam is normative-doctrinal, firmly acknowledging the concept of justice and equality between men and women [1]. Justice and gender equality are based on principles that position the same men and women as God's servants. The principles of justice and gender equality and the human rights protection (juridical) are legally affirmed also in the Universal Declaration of Human Rights (DUHAM) 1948 as the International Human Rights Law, contained and affirmed that the right of justice and freedom is indispensable to any human being without discrimination, including non-discrimination on the basic need of sex, equal degree between women and men[2] Particularly in the context of the women's rights protection, the international community has formulated the Convention on the Elimination of All Forms of Discrimination against Women or called the CEDAW[3]. 
But ironically, the reality tends to the contrary, the status and roles of women in various societies up to now generally still in a position and conditions that are very worrisome[4]. Women experience a variety of injustices. The form of gender injustice in the form of the marginalization process of women is an impoverishment of one particular gender in this case due to the existence of a culture of patriarchism and gender differences, gender inequality causing inconvenience and the loss of women's freedom as human beings [5]. The assumption that women are inferior to men raises the doctrine of injustice and inequality between men and women who then gave birth to the values of patriarchism [6]. The universally established and centuries-old construction of a centuries-old patriarchic culture is no longer seen as an imbalance, even this is claimed to be a "scientific fact" [7].

Particularly in this research is the injustice experienced by women in indigenous society Lampung Pepadun in Marga Anak Tuha Central Lampung [8]. The first injustice in the context of the heirs, that the daughter and wife or widow in Lampung Customary Law Pepadun Marga Anak Tuha are not entitled to the right of inheritance. This means that girls do not get the inheritance from the relics of their parents. In addition, the woman (wife) did not get a share of the estate of her deceased husband, when the husband died provisions in the customary law of Lampung Pepadun treasures returned and managed by the family of her late husband. The legal system of the traditional inheritance of Lampung Pepadun, certainly different from the concept of inheritance law system in Islam.

The second injustice in the context of marriage, in question, is that: First, after the husband dies, a widow is not allowed to return to her parent's home (settled). This is because, after marriage, women have automatically entered the family system and family law of her husband. Thus, the wife is not allowed to return or settle in the home of her family/parents. Second, if the widow wants to remarry is required to marry with relatives of the deceased husband. Third, if the marriage was done with a man who is not a relative of the deceased husband then they (widows and prospective husbands) are required to perform traditional ceremonies.

If the widow and prospective husband from outside her ex-husband's family still insist on marriage, by not performing the traditional ceremony first as determined in the customary law, there are consequences that will be borne by the divorced widow and implicated to widow's rights. Whereas a wife who was left dead by her husband is very human if he wishes to build a marriage back (married) course after passing iddah period. However, in the Lampung Pepadun community, if there is a widow (due to being left dead by her husband) is advised if she will get married, her future husband is expected to come from the family of the deceased husband. However, if a widow wants to marry someone who is outside the husband's family is allowed but there are custom requirements that must be met first. If the customary requirement is not carried out then the widow's custom is considered dead or has been considered lost and never existed. This is of course very influential for widows who want to remarry because it is closely related to the rights that should be accepted by the widow such as inheritance rights, childcare rights and other rights.

The injustice suffered by indigenous women of Lampung Pepadun Marga Anak Tuha as above, according to the opinion of the writers is very interesting to be studied and studied in depth by using an approach of analysis of the International Convention. The International Convention in the context of women's justice and gender is the CEDAW.

Ratify the CEDAW which is the embodiment of the mandate of the 1945 Constitution which expressly states that all citizens are the owners of the same status in the law, therefore, all forms of discrimination against women shall be terminated because it is inconsistent with Pancasila and the Constitution 1945 [9]. The focus of this study is: (1). What are the rights of women justice in the customary law of Lampung Pepadun Marga Anak Tuha Perspective of CEDAW? 
(2). What efforts to uphold the justice and gender equality of women of Indigenous people of Lampung Pepadun Marga Anak Tuha?

\section{Theoretical Review}

\subsection{The Subordination of Women}

Subordination means a judgment or assumption that a role performed by one gender is lower than the other. Subordination arises as a result of the gender view of women. Attitudes that place women in positions that are not important arise from the assumption that women are emotional or irrational so that women can not appear to lead is a form of subordination in question. The gender-subordinated process of subordination takes place in all sorts of different mechanisms from time to time and from place to place. In life in society, household, and state, many policies are issued without regard to the importance of women. For example; the existence of regulations issued by the government where if the husband will go to study (far from the family) can make their own decisions while for the wife must be permitted by the husband. In households, for example, in limited household finances, it is often heard that there is a priority to go to school for men rather than women, because there is a presumption that women do not need to go to high school anyway, eventually going to the kitchen as well. Things like this actually come from an unjust gender consciousness.

The form of gender inequity above actually stems from a common source of mistakes, male and female gender stereotypes. Stereotype itself means giving a raw image or label/stamp to a person or group based on an erroneous or perverted assumption [10]. Labeling or negative marking of a particular group or sex, commonly called stereotypes. Labeling is generally done in two or more relationships and is often used as an excuse to justify action from one group over another.

Labeling also indicates a lame or unbalanced power relation aimed at conquering or controlling the other side. Negative labeling can also be done on the basis of gender assumptions. But often negative labeling is imposed on women. The consequences of this stereotype usually arise from discrimination and various injustices. One form of this stereotype is sourced from a gender perspective. There are so many stereotyped forms that occur in a society that is attached to women generally that they are difficult, limiting, impoverishing, and disadvantageous to women. Not to mention the subordination is also experienced by women in Lampung Pepadun Marga Anak Tuha community, Central Lampung District. Where women in these indigenous communities gain injustice both in inheritance and in family scope or marriage.

In fact, the CEDAW contains basic principles such as justice. Justice and gender equality are based on principles that position the same men and women as God's servants.

\subsection{Convention on the Elimination All Forms of Discrimination Against Women (CEDAW)}

The CEDAW is a standard of international instrument adopted by the United Nations (UN). Precisely on December 18, 1979, the UN General Assembly adopted a draft the CEDAW [11]. The CEDAW entered into force on 3 December 1981(Asnawi, 2012a). The United Nations General Assembly invites member states of the United Nations to ratify it, accounting for 180 nations more than ninety percent of the member states of the United Nations, is a State Party to this Convention.

The CEDAW is the only international human rights instrument that provides a comprehensive framework for respecting, protecting and fulfilling the rights of women [12]. 
The Convention aims to eliminate all forms of discrimination against women and often referred to as the Women Convention. The CEDAW is the most comprehensive and recognized worldwide convention as the Bill of Rights for Women. The approval of CEDAW is the culmination of international efforts in the decade of women aimed to protect and promoting worldwide women's rights [13].

Indonesia Member State of the United Nations which is also a participating State in the establishment of CEDAW Convention has also ratified through the Act. No. 7 of 1984. The meaning of the ratification of an international convention by law is the treaty which it ratifies will create the obligations and the accountability of the State ratifying it. Ratification by the government and the approval of the House of Representatives make the principles and provisions of the Convention as formal law and a part of national law. With the ratification of this Women Convention, Indonesia has legally binding on international treaties that have nondiscrimination, substantive equality and the obligations of this State.

Basically, gender differences are not a problem when it is not a socio-cultural problem, namely the existence of gender inequality which then results in various forms of injustice and oppression of citizens with a certain gender. In reality, however, gender differences have given birth to various injustices, especially women. The assumption that women are inferior to men raises the doctrine of injustice and inequality between men and women who then gave birth to the values of patriarchism. The centuries-old construction of centuries-old centuries-old patriarchic culture is no longer seen as an imbalance, even it is claimed to be a "scientific fact". With the birth of CEDAW, it is expected that justice and gender equality can be realized well in the aspects of life. Without discrimination, subordination and other human rights violations.

\section{Method}

This type of research is field research (field research) based on ethnography. Approach method in this writing using qualitative approach. Primary data sources used in this study were divorced widows 20 people, family of the deceased husband of divorced widow 20 people, indigenous leaders lampung pepadun marga anak tuha 11 people, head of village from 11 villages in Anak Tuha and Padang Ratu sub-district.

Data collection techniques used in this research is through 1). Observation is a review activity undertaken at the research site by recording, photographing, and recording of the situation and the conditions and on-site legal events. The observation was conducted to see the location of the customary events related to divorce in indigenous people of Lampung Pepadun in Marga Anak Tuha Central Lampung. 2). Interviews are primary data collection activities that are sourced directly from the respondents of the research in the field (location). Interviews were conducted with divorced widows and families of husbands who died in Lampung Pepadun Marga Anak Tuha, indigenous leaders Lampung Pepadun Marga Anak Tuha, Marga Anak Tuha religious leaders and government leaders Marga Anak Tuha Central Lampung.

In analyzing research data using inductive thinking method. The inductive method induced is to depart from concrete factors and events. Then from the concrete factors and events are drawn generalizations that are general. The inductive method was used, among others, by starting from a number of customary events on the subordination of women in Lampung Pepadun society that were studied, then drawn a general conclusion, meaning whether women's rights in Lampung Pepadun Marga Anak Tuha Central Lampung are in accordance with the principles of justice Gender is organized in CEDAW as well as Islamic law. 


\section{Result and Discussion}

\subsection{Women's Justice Rights in Customary Law Lampung Pepadun Marga Anak Tuha the Perspective of CEDAW}

In the traditional legal system of Lampung Pepadun Marga Anak Tuha, the inheritance is only given to the boy while the girl and the widow left by her husband are also not entitled to inheritance. This is because the indigenous system of Lampung Pepadun is a patrilineal society whose structure is drawn according to the father line (male line), while the maternal lineage is removed. In this patrilineal kinship, the boy's position becomes very important because he is considered a hereditary successor. Unlike the case with women. Among indigenous people of Lampung Pepadun every daughter of a woman will consider herself another child because from childhood until the adult daughter is prepared to be a child of others and become indigenous people of others.

In addition to the daughter, the wife/widow does not get the share of the estate of her deceased husband, when the husband dies provisions in the customary law of Lampung Pepadun treasures returned and managed by the family of her late husband. A widow left by her husband has no share of the inheritance because the wife is not the heir of her husband. The estate of the deceased husband is passed on to the children (the eldest son) from the result of their marriage. The legal system of traditional inheritance of Lampung Pepadun, certainly different from the concept of inheritance law system in Islam.

The second injustice in the context of marriage, in question, is that: First, after the husband dies, a widow is not allowed to return to the home of her parents (settled). This is because, after marriage, women have automatically entered the family system and family law of her husband. Thus, the wife is not allowed to return or settle in the home of her family/parents. Second, if the widow wants to remarry is required to marry with relatives of the deceased husband. A widow in the traditional Lampung Pepadun if you want to remarry is expected to marry the relatives (relatives) of the deceased husband (marriage Leviraat / Nyemalang). Third, if the widow does not want to marry the relatives of the deceased husband then there is a custom requirement that must be fulfilled first (unites the blood) so that the husband candidate can replace the position of the deceased husband either as a son of his parents, head of household or the position of the deceased dyad, namely the prospective husband must be appointed as a child first customary by the deceased husband's parents. With the appointment of the husband candidate then the customary candidate of the husband has replaced the status of the deceased husband both customarily and responsibly as head of the family. If the customary law requirements are not implemented then there are consequences that will be borne by the widow [14].

If the widow and future husband from outside the family of her ex-husband are still forced to continue to perform the marriage, by not performing custom ceremonies as prescribed in the customary law, there are consequences that will be borne by the divorced widow and implicate the rights the widow. Whereas a wife who was left by her husband is very human if he wishes to build a marriage (wedding) course after passing the iddah period without having to be burdened with provisions that incriminate the widow and prospective husband (from outside the family of her ex-husband).

Discrimination and injustice suffered by indigenous women of Lampung Pepadun especially Marga Anak Tuha as described above, if viewed from the perspective of International Convention which is the CEDAW, it can be said that the practices of adat law mentioned above are very contradictory and contrary to the principles and principles contained in the provisions of the CEDAW. 


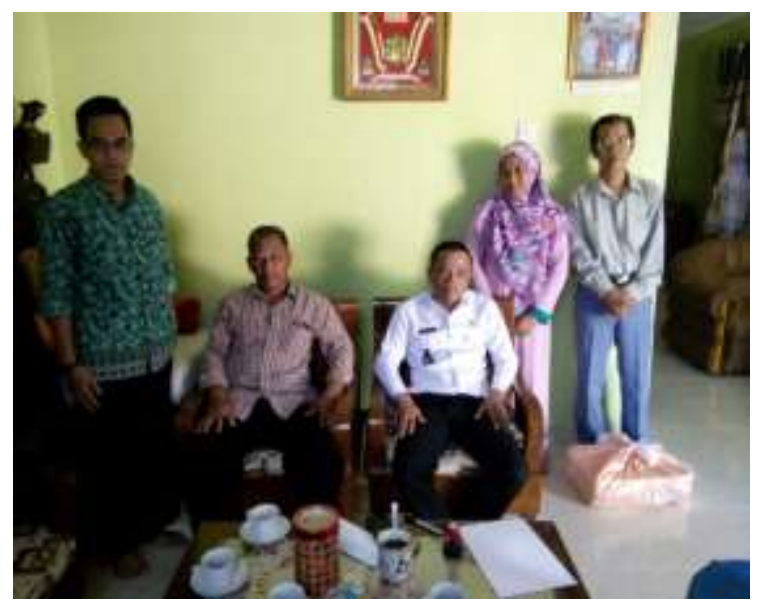

Figure 1: Interview with a custom leader.

Therefore, the formulation of customary law of Lampung Pepadun Marga Anak Tuha, as well as the forms of practices which tend to be biased and discriminated against indigenous women of Lampung Pepadun as above, are clearly not in accordance with Article 15 of the CEDAW Convention which states that: the state is obliged to give women equal rights with men before the law ". The customary law of Lampung Pepadun Marga Anak Tuha, states that women are not entitled to inheritance rights, who are entitled to inheritance rights are boys. This can be seen in the distinction between men and women before the customary law, it is of course when viewed from the perspective of CEDAW women experience inequality between men especially in the context of inheritance rights.

It also goes against the principle of CEDAW Convention on the principle of NonDiscrimination. It is made clear that "any distinction, exclusion or restriction made on the basis of sex, has the effect or purpose to reduce or eliminate the recognition, enjoyment or use of human rights and fundamental freedoms in the economic, social, cultural, civil or any other field by women, regardless of their marital status, on the basis of equality between men and women ". (CEDAW Article 1)

Another injustice as above, that women if married by their own choice which husband candidate is taken from outside the family of her deceased husband, while still not performing traditional ceremonies/rituals that have been set in customary law, there will be consequences that can be accepted the widow. If the customary requirement is not executed then the widow's custom is considered dead. This is of course very influential for the divorced widow who wants to remarry because it is closely related to the rights that should be accepted by the widow such as inheritance rights, child protection rights and other rights [14].

In the perspective of the CEDAW Convention the provision is also contradictory as Article 16 Point (a) states that "the same right to marriage" and point (b) stipulates that: "The same right to freely choose a spouse and to enter the marriage ladder only with free and full consent ".

The indifference suffered by indigenous women of Pepadun Marga Anak Tuha as above, in addition to contradictory to CEDAW, is also contrary to the principle of "equality before the Law" which is the principle of "equality before the law". This principle is contained in the 1945 Constitution Article 28B paragraph (1) and (2) and Article 28D Paragraph (1) which reads: "Everyone shall have the right to fair recognition, guarantee, protection and legal certainty and equal treatment before the law". This is certainly in line with the principles of the rule of law which includes 5 (five) terms, one of which is the principle of equality before the Law of this 
principle in a law state meaning that the government shall not privilege any particular person or group of persons; discriminates against a particular person or group of people.

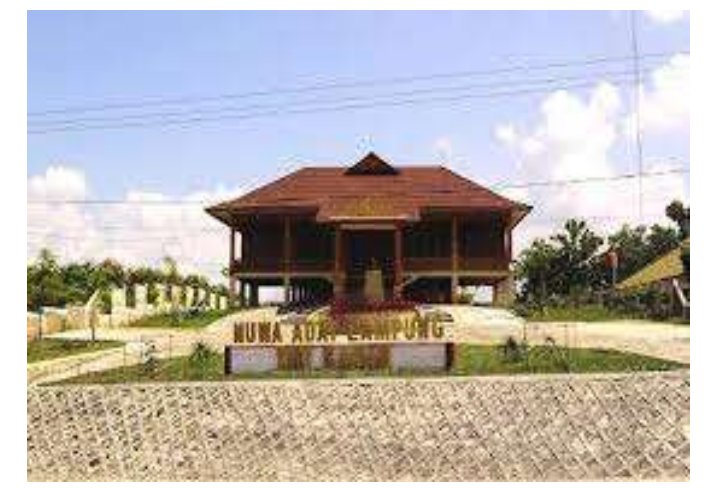

Figure 2: Traditional house of Lampung pepadun community.

Within this principle, it contains (a) the existence of a guarantee of equality for all persons before the law and government, and (b) the availability of mechanisms to demand equal treatment for all citizens. Thus customary law or legislation should provide fair protection and legal certainty to women, and the rights to it [15]. Therefore, in view of these facts, the government should not neglect the right of women of indigenous communities of Lampung Pepadun Marga Anak Tuha and the government to demand efforts to protect and fulfill the rights of women.

This is as confirmed by CEDAW Convention Section 3 which states that "States Parties shall take all necessary measures, particularly in the political, social, economic and cultural fields, including the enactment of legislation, to ensure the development and promotion and full protection of women, with the aim of ensuring for them the application and enjoyment of human rights and fundamental freedoms on an equal basis with men ".

In addition, the CEDAW Convention Article 2 (b) - (e) - (f) - (g) states that: States Parties condemn discrimination against women in all its forms, agreeing to exercise in all appropriate means and without delay implement the policy to eliminate discrimination against women and, to achieve the aims, the state shall: Point (b) The State shall adopt appropriate legislative and other measures, including sanctions where necessary, prohibiting all acts of discrimination against women; Point (e), the State shall take all necessary measures to eliminate discrimination against women by any person, organization or enterprise; Points (f) The State shall take all necessary measures, including the establishment of legislation, to amend or delete existing laws, regulations, customs and practices that are discriminatory against women; Points (g) Remove all national criminal provisions that are discriminatory against women.

\subsection{Efforts to Enforce Justice and Gender Equality of Women of Indigenous People of Lampung Pepadun Marga Anak Tuha}

Efforts to uphold justice and human rights of women in normative can be quite maximal. This is evidenced by ratifying the CEDAW through the Act. No. 7 of 1984 on the Endorsement of the Elimination of All Forms of Discrimination Against Women. Then the government also ratified the International Covenant on Civil and Political Rights (ICCPR) through the Act. No. Law No. 12 of 2005 on Ratification of the International Covenant on Civil and Political Rights 
and the International Covenant on Economic, Social and Cultural Rights (ICESCR) through Law No. 11 of 2005 on Ratification of the International Covenant on Economic, Social and Cultural Rights. An important effort is made in upholding gender justice for women of Lampung Pepadun Marga Anak Tuha community:

\subsubsection{Socialization of Gender-Based Education.}

The socialization of gender-based education is devoted to the women's community of Lampung Pepadun Marga Anak Tuha itself. The purpose of this gender-based education is the deep awareness of women, to realize that women are essentially equal before the law and in any field, women also have the same rights as men. Therefore, gender-based education is important to do, because so far it is one of the obstacles in the effort to uphold justice and gender equality is found in women themselves. Although it can not be denied that the cultural, environmental, and cultural structures of stereotypes in society are the contributing factors, it is often difficult for women to find their identities personally, as a result of a culture that causes women to find it difficult to remove feelings of shame and guilt. Personal ambition driven by uncontrollable emotions will manifest unhealthy thoughts, as well as the stereotypical views that have penetrated into the mental psyche of women, causing women to often fall behind in decision making [16].

\subsubsection{Socialization of Gender-Based Education and Human Rights for Indigenous People of Lampung Pepadun Marga Anak Tuha.}

This is not less important, to be socialized and understood by the customary leaders or local custom leaders. Because the customary law, customary rules and customary culture that run all this are all with the agreement of local communities and permission from local custom leaders. One of the obstacles in upholding women's justice and gender equality is the lack of understanding of society, especially the indigenous people of Lampung Pepadun Marga Anak Tuha regarding the nature and noble principles of justice and gender equality and human rights. Therefore, gender and human rights education are widely given to the people of Lampung Pepadun Marga Anak Tuha according to writing is a necessity that must be done.

\subsubsection{Understanding to the Whole Community about the Meaning of Religion Correctly and Comprehensively.}

During this time, many people who misunderstand the meaning of religion or the verses contained in the holy book. This external factor can be a very serious threat in the effort to uphold women's justice and gender equality. For example Religion and society. The majority of Indonesians believe that husbands are family leaders. The Qur'an has stated that men (husbands) are the leaders of women (wives), from this verse the position of men is higher than that of women, which justifies the husband to do the beating of the wife (Quran an-Nisa' [4]: 34). Many scholars comment that it is necessary to re-eat the verse and need the full meaning of the verse to the verse. The culture of Indonesian society based on religion is a patriarchal culture which tends to put men in a higher position than women. This patriarchal way of thinking has accumulated created this way of thinking into all aspects of life, thus hegemony and considered natural, natural and considered nature [17]. Therefore, women feel a very big impact, namely, in the field of education, education considered not suitable for women, because the task of women is the domestic sector alone is not public. 


\subsubsection{Changing the Culture of Patriarchism.}

It can not be denied that the obstacles in upholding women's justice and gender equality are the strength of the patriarchal culture inherent in the minds or minds of the people. Therefore, changing the culture of patriarchism is one of the important efforts to be undertaken. Releasing from the "Patriarchal Paradigm" is the right step, a number of studies on human rights explain that the first obstacle in strengthening women's rights is cultural factors. Our society is still very strong adherents patriarchal cultural values that are certainly not conducive to the efforts of women's rights enforcement.

\section{Conclusion}

The right of women in the customary law of Lampung Pepadun Marga Anak Tuha is inconsistent and contradictory to the principles and principles contained in the CEDAW. In this Convention mandates the importance of the realization of equality before the Law "in human life. Moreover, Indonesia has ratified the Convention by Law. No. 7 of 1984. The consequence is that the state (ratification) is obliged to implement the principles contained in the Convention in a manner that is committed, through laws, policies or programs in order to protect, uphold justice, equality and the elimination of all forms of discrimination against women. This includes changing customs and cultural practices based on the inferiority or superiority of either sex.

Efforts to uphold gender equality and fairness of indigenous people of Lampung Pepadun Marga Anak Tuha are: The need for socializing gender-based education and human rights. Socialization and understanding are not only in designation for women, but also the wider community and traditional leaders Lampung Pepadun Marga Anak Tuha. The socialization of education and understanding needs the support of local communities and traditional leaders of Lampung Pepadun. In addition, the effort must be done is, the meaning of religion and verses of the holy correctly and comprehensively. No less important is the need to change the culture of patriarchism into a democratic culture based on gender justice and human rights. Genderbased education and human rights is a necessity that must be done.

\section{References}

[1] D. Ferricha, Sosiologi hukum \& gender: interaksi perempuan dalam dinamika norma dan sosio-ekonomi. Malang: Bayumedia Pub., 2010.

[2] S. sadli, Hak Asai Perempuan Adalah Hak Asasi, Dalam Pemahaman Bentuk-Bentuk Tindak Kekerasan Terhadap Perempuan Dan Alternatif Pemecahannya. Jakarta: Pusat Kajian Wanita dan Gender, 2000.

[3] H. S. Asnawi, "Kritik Teori Hukum Feminis Terhadap UU No. 1 Tahun 1974 Tentang Perkawinan: Suatu Upaya dalam Menegakkan Keadilan HAM Kaum Perempuan," AlAhwal J. Huk. Kel. Islam, vol. 4, no. 1, pp. 117-130, Sep. 2016.

[4] M. Fakih, Menggeser konsepsi gender dan transformasi social. Yogyakarta: Pustaka Pelajar, 1996.

[5] H. S. Asnawi, "Politik Hukum Putusan MK No. 46/PUU-VIII/2010 Tentang Status Anak di Luar Nikah: Upaya Membongkar Positivisme Hukum Menuju Perlindungan HAM," J. Konstitusi, vol. 10, no. 2, pp. 239-260, May 2016.

[6] Sahbana, Wanita Indonesia dalam Keluarga Perspektif Islam. Yogyakarta: UIN Press, 2001.

[7] S. Ruhaini Dzuhayatin, “Teologi Feminis Islam,” Teol. Gema, vol. 55, 2002. 
[8] WAKAPELA, "Wadah Komunikasi Perantau Lampung," WAKAPELA. .

[9] H. S. Asnawi and A. Setiawan, "Politik Hukum Perlindungan HAM di Indonesia (Studi Hak-Hak Perempuan di Bidang Kesehatan)," J. Mahkamah Kaji. Ilmu Huk. Dan Huk. Islam, vol. 2, no. 1, 2017.

[10] M. A. Mushodiq, "Teori Identitas dalam Pluralisme Agama dan Identitas (Fenomena Pluralisme dan Toleransi Beragama Desa Jrahi, Gunungwungkal, Pati, Jawa Tengah),” FIKRI J. Kaji. Agama, Sos. dan Budaya, pp. 379-406, Dec. 2017.

[11] H. S. A and A. Setiawan, "Politik Hukum Perlindungan HAM di Indonesia (Studi HakHak Perempuan di Bidang Kesehatan)," J. MAHKAMAH Kaji. Ilmu Huk. Dan Huk. Islam, vol. 2, no. 1, pp. 77-102, Oct. 2017.

[12] Kalyanamitra, "Pelatihan CEDAW untuk aktivis LSM," Blog Kalyanamitra. .

[13] H. S. Asnawi, "Politik Hukum Kesetaraan Kaum Perempuan Dalam Organisasi Masyarakat Islam Di Indonesia,” Musãwa J. Stud. Gend. dan Islam, vol. 11, no. 1, pp. 67-84, Jan. 2012.

[14] M. Matsani, No Title. 2017.

[15] L. Andaryuni, Hak-hak Perempuan dalam KHI Perspektif CEDAW. Yogyakarta: PUSHAM UII., 2012.

[16] A. N. P. Murti, Getar Gender. Magelang: Indonesia Tera, 2003.

[17] S. W. Hesti Utami, Kesetaraan Gender: Langkah Menuju Demokratisasi Desa. Yogyakarta: IP. Lappera Indonesia, 2001. 